doi:10.20312/dim.2015.05

\title{
Az alkalmazott matematika tantárgy oktatásának sokszínűsége és módszertanának modernizálása az MSc képzésében
}

\author{
Horváth-Szováti Erika \\ NyME EMK Matematikai Intézet \\ horvath-szovati.erika@emk.nyme.hu
}

\begin{abstract}
ÖSSZEFOGLALÓ. A matematika oktatás modernizálása a felsőoktatásban nagyon időszerü. A matematikai jelölésrendszer elsajátítása, a matematikai gondolkodásmód kialakítása és a problémamegoldó készség fejlesztése a legfontosabb cél.
\end{abstract}

ABSTRACT. The modernization of mathematics teaching in higher education is very timely. The notation used in mathematics to learn, develop problem-solving skills and the development of mathematical thinking is the most important goal.

\section{Bevezetés}

Egyre több felsőoktatási intézmény oktatóiban merül fel az a gondolat, hogy az egyetemi hallgatókat nem lehet a hagyományos módszerekkel tanítani. A 10-20 évvel ezelött használt oktatási módszerek (a tételek, bizonyítások vizsgán történő szigorú számonkérése, szóbeli vizsgáztatás, stb.) válságban vannak. Sokszor szembesülünk a régi módszerek negatív következményeivel. Ilyen például az, hogy a diákokban kialakult tudás nem valódi, hanem látszólagos, azaz nem megérteni próbálják az anyagot, hanem csupán értés nélkül memorizálni, és a későbbiekben az ismereteket nem képesek önállóan alkalmazni. Egyre többen értünk egyet abban, hogy oktatás-módszertani megújulásra van szükség a felsőoktatásban. A mesterképzés a mai formájában a 2009/10-es tanévben indult, a Nyugatmagyarországi Egyetem EMK és SKK karain az alkalmazott matematika tárgy oktatását a második évtől, a 2010/11-es tanévtől kezdve vettem át nyugdíjba vonult kollégáktól. A tantárgyi program kidolgozása elődeim munkája, de jelenlegi tantárgyfelelősként az oktatás módszertanát és a vizsgáztatás rendszerét - véleményem szerint a mai kor elvárásaihoz jobban igazodva - megváltoztattam. Ebben a cikkben az azóta összegyüjtött tapasztalataimat szeretném összegezni.

\section{A matematikai oktatás során felmerülő általános problémák}

Az MSc-s hallgatók matematikai alapismeretei - más egyetemek oktatóinak véleménye alapján is - sok esetben hiányosak. Ennek többféle oka lehet. Egyrészt a mesterképzés hallgatói sokféle föiskolai, egyetemi előélettel rendelkeznek, emiatt a BSc képzésben nem teljesen ugyanazt a tananyagot és nem ugyanakkora óraszámban tanulták. Másrészt a BScMSc rendszer különbözeti vizsgákkal ugyan, de meglehetősen nagy átjárhatóságot biztosít az egyes szakok között. Például környezetmérnöki MSc szakon találkozhatunk olyan hallgatóval is, aki a BSc diplomáját földrajz vagy biológia tanári szakon szerezte, emiatt az alapképzésben sokkal kevesebb matematikát tanult, mint a mérnökhallgatók. A matematikai 
hiányosságok egy másik oka az, hogy az utóbbi 10-20 évben a felsőoktatás „,bemeneti oldalát” nézve két nagy változást történt: tömegessé vált a felsőoktatás (ez a folyamat már a 90-es években megindult), illetve a 2004/05-ös tanévben bevezették a kétszintü érettségit. Az általunk jelenleg oktatott hallgatók közül kevesen érettségiztek emelt szinten valamilyen tárgyból, matematikából pedig szinte senki sem.

Az Oktatási Hivatal honlapján közzétett prezentációkat (1. ábra) elemezve egyértelmüen látszik, hogy - a kétszintü érettségi bevezetésétől függetlenül - matematikából minden évben gyengébb eredmények születnek a többi tárgyhoz viszonyítva. Tehát a kétszintü érettségi bevezetése látszólag nem okozott változást. Az azonban észrevehető, hogy a kétszintü érettségi középszinten az elégségesek relatív gyakoriságát kissé növelte és közepesekét csökkentette, továbbá kevesebb a jeles, mint a kétszintü érettségi bevezetése előtt volt. Az utolsó öt év adatai alapján azt mondhatjuk, hogy napjainkban a diákok kb. 70\%-a legfeljebb közepes osztályzatot szerez a középszintü érettségin, és a mi egyetemünkre jelentkezők legnagyobb része feltehetőleg közéjük tartozik.

Jegyeloszlás összes tárgy 2001-2003 (átlag)

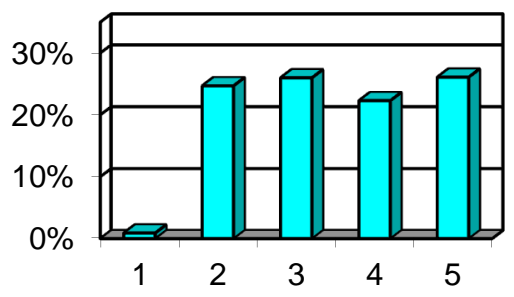

Jegyeloszlás matematika 2001-2003 (átlag)

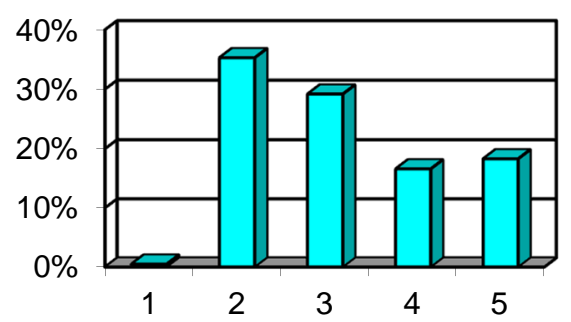

Jegyeloszlás összes tárgy középszint 2011-2015

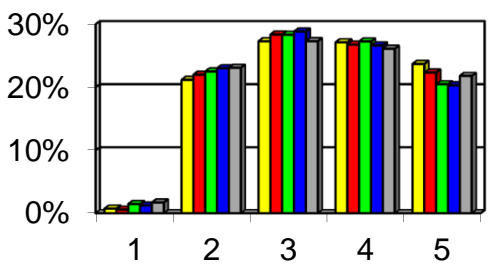

Jegyeloszlás matematika középszint

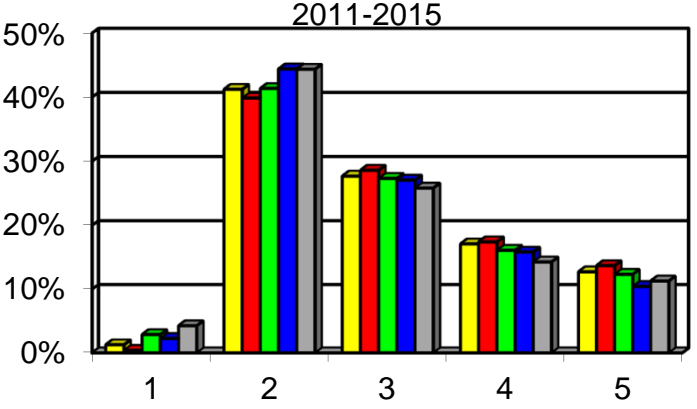

1. ábra. Az érettségi jegyek eloszlása a kétszintű érettségi bevezetése előtt és 2011-15-ben

Az elégségesek számának emelkedése különösen elgondolkodtató, mert a középszintü matematika érettségi jegyek nem ugyanazt a tartalmat tükrözik, mint a korábbiak. A középszintü matematika érettségiből kikerültek a bizonyítások és a komplex feladatok. Ez azért sajnálatos, mert meggyőződésem szerint a matematikaoktatás egyik célja egy speciális gondolkodásmód kialakítása, a logika fejlesztése. Több mint 10 éves érettségi elnöki tapasztalattal rendelkezem a középszintü érettségiken. Ennek során lehetöségem van a legkülönfélébb középiskolák matematika szakos tanárainak véleményét megismerni. Legtöbben egyetértenek abban, hogy a bizonyítások, illetve a viszonylag komplexebb feladatok hiánya megváltoztatta a matematika középszinten történő oktatását. Gyakorlatilag a szaktanárokon múlik, hogy bizonyításokat, gondolkodásra serkentő, összetettebb feladatokat milyen mértékben tanítanak, illetve milyen (általában elemi) szinten kérik ezeket számon. 
Tehát az alapképzésekbe belépő hallgatók valószínüleg nem rendelkeznek olyan fokú problémafelismerő, problémamegoldó készségekkel, mint elődeik.

Összefoglalva: a matematikaoktatásnak, sőt az egész felsőoktatásnak valamilyen oktatásmódszertani megújulásra van szüksége, mivel - úgy tünik - egyrészt az eddigi módszerekkel látszólagos tudást szereztek a hallgatók, másrészt elmaradás tapasztalható a korábban megszokott gondolkodásmódban, problémamegoldó készségekben. A megújulás azt jelenti, hogy a korábbi tematikákat át kell tekintenünk például abból a szempontból, hogy

1. mi a kimeneti követelmény (kiket képzünk),

2. mi a matematika oktatásának célja,

3. milyen matematikai tudásbázisra építhetünk,

4. amit tanítani próbálunk, az mennyire áll közel a gyakorlati élethez,

5. mit és milyen mélységben oktassunk,

6. hogyan vélekednek a hallgatók a matematikaoktatásról.

\section{Az alkalmazott matematika oktatásának sokszínűsége és módszertanának modernizálása a NyME EMK és SKK Karain MSc képzésben}

\subsection{A matematika oktatás célja}

A felsőfokú matematikai mủveltség manapság egyre szélesebb körben hasznosítható. A szerteágazó matematikai alkalmazások szükségessé teszik, hogy a mérnökhallgatók - azok is, akik nem müszaki, hanem agrár, vagy egyéb szakterületre készülnek - olyan matematikai alapmüveltségre tegyenek szert, amelynek segítségével a későbbi pályájuk során előforduló matematikai problémákat megértik, és egyedül, vagy kisebb segítséggel meg tudják oldani. Fontos célunk az alapos, alkalmazható, mủvelhető matematika tudomány átadása. Szeretnénk a hallgatókkal megismertetni a matematika jelölésrendszerét, a felsőbb matematika eszköztárát, a leggyakrabban előforduló gyakorlati módszereket a különböző témakörökben (egy- és többváltozós függvénytan, lineáris algebra, valószínüségszámítás és statisztika).

A piac a végzett hallgatóktól azt várja el, hogy olyan szakemberek legyenek, akik

1. felismerik a vizsgálandó probléma esetleges matematikai vonatkozásait,

2. azt le tudják fordítani a matematika nyelvezetére,

3. ki tudják választani (esetleg segítséggel) a megoldáshoz szükséges matematikai módszert,

4. azt végre tudják hajtani (vagy ha a megoldásban segítséget kérnek, akkor a megoldás menetét - legalább vázlatosan - képesek megérteni),

5. a kapott megoldást tudják értelmezni,

6. az eredményeket vissza tudják fordítani a szakterületük nyelvezetére,

7. más területeken is jó problémamegoldó képességgel rendelkeznek (ez a matematika tanulás egy fontos pozitív hozadéka).

A hallgatóknak az egyetem felé irányuló két legfőbb elvárása az, hogy

1. a megszerzett tudás a gyakorlatban alkalmazható legyen, és

2. a vizsgát sikeresen teljesítsék.

A hallgatók első elvárásának nagyon nehéz megfelelnünk, mert a matematikának az ő szakterületükön történő gyakorlati alkalmazhatóságát sajnos sokszor megkérdőjelezik. Nem látják be, hogy a matematikai gondolkodásmód kialakulása a problémamegoldó készséget más területeken is javítja. Ezt mi, oktatók a matematikai tájékozatlanságukkal, a tárgy iránti - 
legtöbbször a kudarcokból fakadó - ellenérzéseikkel magyarázzuk. A hallgatók, mint „vevők” jogosan várnak el a tanulással, a tananyaggal, mint termékkel kapcsolatos minden segítséget, azaz „szolgáltatást”. Ebben a felfogásban az oktató szerepe megváltozik. Az oktató közvetítő szerepet tölt be a hallgatók és a piac között. Meg kell találnia az elmélet és a gyakorlat helyes arányát, meg kell tudnia határozni tudományterületének azon elemeit, illetve ezen elemek olyan formáit, amelyek a gyakorlatban leginkább hasznosíthatók.

Az oktatás tárgyának, formájának és mélységének dilemmái nem csak a matematikaoktatás sajátosságai. Valószínüleg ezekkel a problémákkal bármely tantárgy, illetetve tantárgycsoport szembekerült, vagy szembe fog kerülni. Azonban látható, hogy ha bármely tantárgy esetében változtatást vezetünk be, az kihathat más tantárgyak oktatására is, ezért amikor a matematikaoktatás átalakításáról beszélünk, arról is beszélnünk kell, hogy a többi tantárgy oktatását miként alakítsuk át. Nyilvánvalóan ezeknek a kérdéseknek a megoldásához az egyes szakmacsoportok - jelenleg még eseti jellegü - párbeszéde is szükséges.

\subsection{Az alkalmazott matematika oktatásának sokszínúsége}

MSc képzésben alkalmazott matematika tárgyból mind a két karon folyik oktatás, a tananyagban, az óraszámokban, valamint a követelményrendszerben eltérések vannak (1. és 2. táblázat). Van képzés nappali és levelező tagozaton is, szintén nagyon eltérő óraszámokban. Érdekesség, hogy a könnyüipari mérnöki képzést az Óbudai Egyetem és a Nyugatmagyarországi Egyetem közösen végzi. A hallgatók az első évben döntően Sopronban, a második évben Budapesten tanulnak. Az alaptárgyak oktatása Sopronban, a szakmai tárgyak oktatása Budapesten történik. A papírfeldolgozó szakirány hallgatói a szakmai tárgyak jelentős részét is Sopronban hallgatják.

A hallgatói létszámok egyetemünkön az MSc képzésekben nagyon kicsik, az egyetem honlapján érdeklődők is olvashatják, hogy „kis létszámú évfolyamainkon több idő jut Önre, személyes kapcsolata lehet az oktatóival". A 2. ábrán látható az utolsó öt tanévben (2010/11től 2014/15-ig) a hallgatók összlétszáma a három fő képzési területen (egy tanévre összegezve az adott szakirányban, a két szemeszterben összesen oktatott nappali és levelező tagozatos hallgatók számát).

\begin{tabular}{|c|c|c|c|c|c|c|}
\hline kar & kód & szakirány & képzés & $\begin{array}{c}\text { óraszám } \\
\text { (ea+gyak) }\end{array}$ & $\begin{array}{c}\text { vizsga- } \\
\text { évközi } \\
\text { jegy }\end{array}$ & kredit \\
\hline \multirow{4}{*}{ SKK } & $\begin{array}{l}\text { F2FNMAT } \\
\text { N0,N1 }\end{array}$ & $\begin{array}{c}\text { faipari mérnök, } \\
\text { ipari terméktervező } \\
\text { mérnök }\end{array}$ & nappali & heti $2+2$ & $\mathrm{v}$ & 6 \\
\hline & $\begin{array}{l}\text { F2FLMAT } \\
\text { L0, L1 }\end{array}$ & $\begin{array}{c}\text { faipari mérnök, } \\
\text { ipari terméktervező } \\
\text { mérnök }\end{array}$ & levelező & félévi $12+12$ & $\mathrm{v}$ & 6 \\
\hline & $\begin{array}{c}\text { F2KNMAT } \\
\text { N0,N1 }\end{array}$ & könnyüipari mérnök & nappali & heti $2+2$ & $\mathrm{v}$ & 6 \\
\hline & $\begin{array}{c}\text { F2KLMAT } \\
\text { L0,L1 }\end{array}$ & könnyüipari mérnök & levelező & félévi $15+10$ & $\mathrm{v}$ & 6 \\
\hline \multirow{2}{*}{ EMK } & $\begin{array}{l}\text { EG627-CAA00 } \\
\text { N0,N1 }\end{array}$ & $\begin{array}{l}\text { környezetmérnök, } \\
\text { környezettudományi } \\
\text { szak }\end{array}$ & nappali & heti $2+1$ & é & 3 \\
\hline & $\begin{array}{l}\text { EG627-CAA00 } \\
\text { L0,L1 }\end{array}$ & $\begin{array}{l}\text { környezetmérnök, } \\
\text { környezettudományi } \\
\text { szak }\end{array}$ & levelező & félévi $6+3$ & é & 3 \\
\hline
\end{tabular}

1. táblázat. Az alkalmazott matematika tantárgy óraszámai az egyes képzésekben 


\begin{tabular}{|c|c|c|}
\hline hét & SKK 2ea+2gyak/hét & EMK 2 ea+1 gyak/hét \\
\hline 1. & $\begin{array}{l}\text { Differenciálegyenlettel megoldható szöveges } \\
\text { feladatok }\end{array}$ & $\begin{array}{c}\text { u.a. } \\
\text { (ugyanaz, kevésbé részletesen) }\end{array}$ \\
\hline 2. & $\begin{array}{l}\text { Állandó együitthatós másodrendủ lineáris } \\
\text { differenciálegyenlet megoldása } \\
\text { (konstasnsvariálás és próbafüggvény módszere) }\end{array}$ & 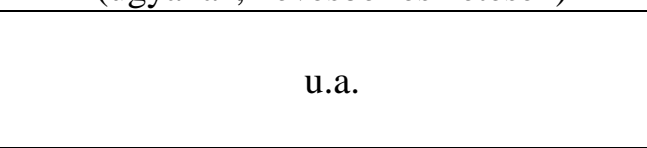 \\
\hline 3. & Differenciálegyenletek megoldása sorbafejtéssel & u.a. \\
\hline 4. & $\begin{array}{l}\text { Többváltozós függvények (kiemelten a három és } \\
\text { több változós függvények) }\end{array}$ & u.a. \\
\hline 5. & $\begin{array}{l}\text { Lokális szélsőérték (Hesse-féle mátrix), } \\
\text { feltételes szélsőérték }\end{array}$ & u.a. \\
\hline 6. & Abszolút szélsőérték & u.a. \\
\hline 7. & $\begin{array}{l}\text { Zárthelyi az 1-6. hét anyagából. } \\
\text { Kétváltozós függvények integrálása (BSc anyag } \\
\text { ismétlése, új anyag: nem origó középpontú } \\
\text { körrel kapcsolatos tartományok) }\end{array}$ & $\begin{array}{l}\text { Zárthelyi az 1-6. hét anyagából. } \\
\text { Két- és háromváltozós függvények } \\
\text { integrálása (BSc anyag ismétlése, új } \\
\text { anyag: hengerkoordináták) }\end{array}$ \\
\hline 8. & $\begin{array}{l}\text { Kétváltozós függvények integrálásának } \\
\text { folytatása (poláregyenletekkel felírható } \\
\text { tartományok, ellipszis tartomány) }\end{array}$ & $\begin{array}{l}\text { Az integrálás alkalmazásai (térfogat, } \\
\text { tömeg, tömegközéppont, felszín) }\end{array}$ \\
\hline 9. & $\begin{array}{l}\text { Háromváltozós függvények integrálása (BSc } \\
\text { anyag ismétlése, új anyag: hengerkoordináták) }\end{array}$ & $\begin{array}{l}\text { Vektor-skalár függvények (csavarvonal), } \\
\text { vektor-vektor függvények, divergencia, } \\
\text { rotáció, gradiens, nabla operátor, Laplace } \\
\text { operátor, vonalintegrál }\end{array}$ \\
\hline 10. & $\begin{array}{l}\text { Háromváltozós függvények integrálásának } \\
\text { folytatása (ellipszoid tartomány) }\end{array}$ & $\begin{array}{l}\text { Statisztikai alapfogalmak ismétlése, a } \\
\text { döntéselmélet alapjai }\end{array}$ \\
\hline 11. & $\begin{array}{l}\text { Az integrálás alkalmazásai (térfogat, tömeg, } \\
\text { tömegközéppont, felszín) }\end{array}$ & Regressziószámítás \\
\hline 12. & $\begin{array}{l}\text { Vektor-skalár függvények (csavarvonal } \\
\text { egyenletének felírása), vektor-vektor } \\
\text { függvények, divergencia, rotáció, gradiens, } \\
\text { nabla operátor, Laplace operátor, vonalintegrál }\end{array}$ & Varianciaanalízis \\
\hline 13. & Zárthelyi a 7-12. hét anyagából & Zárthelyi a 7-12. hét anyagából \\
\hline 14. & Pótló (javító) zárthelyi & Pótló (javító) zárthelyi \\
\hline
\end{tabular}

2. táblázat. Az alkalmazott matematika tananyag heti lebontásban

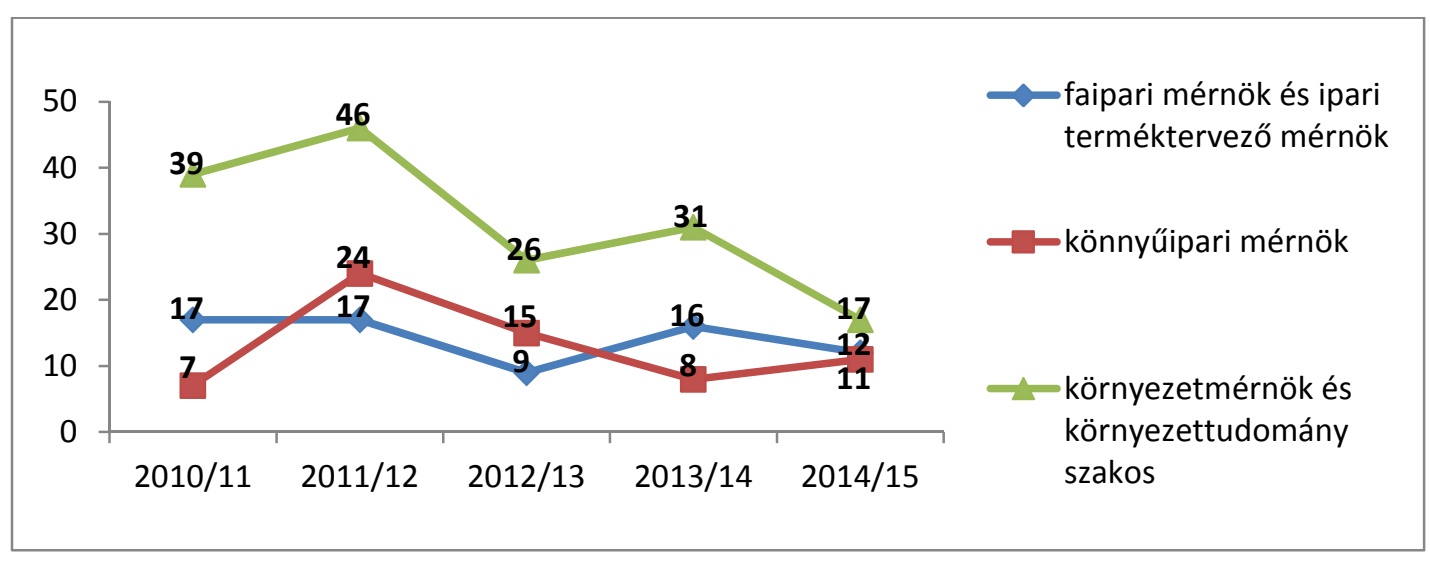

2. ábra. Az MSc képzésben alkalmazott matematikát hallgatók száma az egyes tanévekben 


\subsection{Az alkalmazott matematika oktatás módszertanának és a vizsgáztatás rendszerének modernizálása}

Az alkalmazott matematika tantárgy oktatásának során a cél a matematika jelölésrendszerének helyes használata, és az alkalmazást helyezzük elötérbe a mély matematikai háttérösszefüggések megértése helyett. Az előadásanyagokból PPT készült, amelyen az alapvető tételek, illetve a témákhoz kapcsolódó feladatok és nagyszámú házi feladat szerepel végeredménnyel. Ezt a hallgatók a félév első óráján megkapják, így óra alatt csak a feladatok megoldásának menetét kell a tábláról leírni. A hiányzók is pontosan tudják, hogy mi a heti tananyag. Nem kell memorizálni képleteket, a zárthelyik és a vizsga során használható képletgyüjtemény.

A környezetmérnök és környezettudomány szakos levelezős hallgatók kivételével minden hallgató a félév során két zárthelyit ír. A kivételt képző levelezős kurzus számára három konzultáció van (mindegyik konzultáción 2 előadás és 1 gyakorlat). Az első tanévekben egy pótalkalom beillesztésével lehetőségem volt két zárthelyi íratására, ez azonban nyilván csak a hallgatók beleegyezésével volt lehetséges. Egyre gyakrabban elöfordul, hogy munkahelyi kötöttségekre, utazással kapcsolatos anyagi terhekre és egyéb dolgokra hivatkozva a pótalkalmat nem szavazza meg a csoport, ilyenkor egyetlen „összevont” zárthelyit írnak a harmadik alkalommal. Ez sajnos jóval nagyobb sikertelenséggel zárul, mint amikor két részletben történt a készülés és a számonkérés.

Az alkalmazott matematika az SKK hallgatói számára vizsgaköteles tantárgy, az EMK hallgatói pedig a két zárthelyi pontszámának összegéből kialakított félévközi jegyet kapnak. Az SKK hallgatói a zárthelyik átlagának minimum 40\%-os teljesítése esetén „,rövid vizsga” lehetőségével élhetnek, akik pedig a zárthelyik során nem érik el ezt a szintet, „hosszú vizsgát" írnak. Ennek során az elégséges feltétele mind a gyakorlati, mind az elméleti rész minimum 40\%-os teljesítése. A „rövid vizsga” 60 perces feladatsora két részből áll: „I. Teszt” (30 pont) és „II. Kiegészítendő kérdések” (20 pont) (3-4. ábra). Az I. részben $10 \mathrm{db}$ tesztkérdés van (helyes válasz 3 pont, nincs válasz 0 pont, hibás válasz -1 pont), ezek a feladatmegoldásoknak csak egy-egy részlépésére, az ok-okozati kapcsolatokra kérdeznek rá. A II. rész 5 db 4 pontos, röviden megválaszolható kérdésböl áll (példaadás, képlethasználat, vagy egy-két lépéssel könnyen megoldható feladat). A „rövid vizsgán” is minimum 40\%-ot kell elérni az elégségeshez. A tapasztalat azt mutatja, hogy az ilyen stílusú feladatsorra nem lehet „magolással” készülni, a hallgatók rákényszerülnek a tananyag megértésére. Olyan nagy feladatbankot állítottam össze, hogy a kérdések ismétlődése szinte kizárt. Meglepő módon az ilyen típusú vizsga előbb-utóbb azoknak is sikerül, akik nagyon gyenge alapokkal, viszont kellő szorgalommal rendelkeznek. A végső osztályzat legtöbbször elégséges vagy közepes, de néha egy-egy ebböl kiemelkedő (jó vagy ritkán jeles osztályzatra vizsgázó) hallgatóval is találkozom. A hallgatók kb. 30\%-a sajnos nem tudja az első tárgyfelvétel során teljesíteni a követelményeket, így többször felveszi a tárgyat. Ez leginkább azokkal fordul elö, akik nem kellö hangsúlyt fektetnek a tananyag megértésére.

Érdekes kérdés, hogy a nem nappali tagozatos képzésekbe a fenti módszertan átvihetö-e. Itt a kevesebb kontaktóra miatt lehetséges, hogy a nappali tagozattal szemben aránytalanul megnehezül a tananyag elsajátítása. A levelezős tananyag a nappalis anyag szükített változata, néha tartalmaz kisebb, önállóan feldolgozandó részeket is, természetesen részletes kiadott anyag alapján. Véleményem szerint megengedhető, hogy levelező képzésen kicsit más felépítést kövessünk, de nem szabad megfeledkezni arról, hogy ez a nappali és levelező képzés közötti átjárhatóságot veszélyezteti. Igaz ugyan, hogy szinte soha nem találkozunk levelező képzésről nappalira történő átjelentkezéssel, inkább fordítva fordul elö. 
1. Válasszuk ki azt a differenciálegyenletet, amely homogén részének általános megoldása $c_{1} \sin x+c_{2} \cos x$, $c_{1}, c_{2} \in R$ :
A) $y^{\prime \prime}(x)-y^{\prime}(x)=e^{x}$
B) $y^{\prime \prime}(x)-y(x)=\sin x$
C) $y^{\prime \prime}(x)+y^{\prime}(x)=x^{2}$
D) $y^{\prime \prime}(x)+y(x)=x$

2. Az $y^{\prime}(x)=\frac{1}{2} y^{2}(x)-e^{-x} ; \quad y(0)=-1$ differenciálegyenlet sorbafejtéssel történő megoldásakor a harmadfokú tag együtthatója:
A) $\frac{1}{4}$
B) $-\frac{1}{4}$
C) $\frac{1}{24}$
D) egyik sem helyes

3. A $z=\sqrt{\frac{x^{2}}{12}+\frac{y^{2}}{12}}-3$ grafikon alakja
A) egy forgásparaboloid, melynek csúcspontja $C\left(\begin{array}{lll}0, & 0,3\end{array}\right)$
B) egy forgásparaboloid, melynek az xy síkban lévő metszete egy $r=6$ sugarú kör
C) egy forgáskúp, melynek csúcspontja $C\left(\begin{array}{lll}0, & 0, & -3\end{array}\right)$
D) egy forgáskúp, melynek az xy síkban lévő metszete egy $r=6$ sugarú kör

4. Az $f(x, y, z)=8 x y+\frac{1}{x}-\frac{1}{y}+\frac{1}{2} z^{2}$ függvény Hesse-mátrixának hiányzó elemei: $H(x, y, z)=\left(\begin{array}{ccc}\frac{2}{x^{3}} & 8 & 0 \\ A & B & 0 \\ 0 & 0 & C\end{array}\right)$
A) $A=0, \quad B=\frac{2}{y^{3}}, \quad C=1$
B) $A=8, \quad B=\frac{2}{y^{3}}, \quad C=-1$
C) $A=0, \quad B=-\frac{2}{y^{3}}, \quad C=-1$
D) $A=8, \quad B=-\frac{2}{y^{3}}, \quad C=1$

5. Integráljuk az $f(x, y, z)$ függvényt a $V=\left\{(x, y, z) \in R^{3} \mid x^{2}+y^{2}+z^{2} \leq 1 ; y, z \geq 0\right\}$ véges térrészen. Az integrálás felírása melyik esetben helyes?
A) $\int_{0}^{1} \int_{0}^{\pi / 2} \int_{0}^{\pi} f(r, u, v) \cdot r^{2} \sin u d u d v d r$
В) $\int_{0}^{1} \int_{0}^{\pi / 2} \int_{-\pi / 2}^{\pi / 2} f(r, u, v) \cdot r^{2} \sin u d u d v d r$
C) $\int_{0}^{1} \int_{0}^{\pi / 2} \int_{0}^{\pi} f(r, u, v) \cdot r^{2} \sin u d v d u d r$
D) $\int_{0}^{1} \int_{-\pi / 2}^{\pi / 2} \int_{0}^{\pi / 2} f(r, u, v) \cdot r^{2} \sin u d v d u d r$

6. Az $f(x, y)=x^{2}+\sqrt{3} y$ függvény $T$ tartomány feletti felületének felszíne a következő integrálással számítható ki:
A) $\iint_{T} \sqrt{4 x^{2}+3 y^{2}+1} d T$
B) $2 \iint_{T} \sqrt{x^{2}+1} d T$
C) $\iint_{T} \sqrt{x^{4}+3 y^{2}+1} d T$
D) egyik sem helyes

7. Adott $\bar{v}(x, y, z)=(-z, x,-y)$ és $\bar{r}(t)=(2 t-1,2-3 t, t-1) ; \quad t \in[0 ; 1]$. Ekkor a vektor-vektor függvény vektor-skalár függvény mentén képzett vonalintegrálja:
A) $\frac{1}{2}$
B) $-\frac{1}{2}$
C) 0
D) egyik sem helyes

8. Adott egy $\bar{f}(\bar{r})$ vektormező (vektor-vektor függvény). Ekkor nem létezik
A) $\operatorname{div} \operatorname{rot} \bar{f}(\bar{r})$
B) $\operatorname{grad} \operatorname{div} \bar{f}(\bar{r})$
C) $\operatorname{rot} \operatorname{div} \bar{f}(\bar{r})$
D) $(\bar{f}(\bar{r}) ; \bar{r})$ skaláris szorzat 
1. Adjunk példát olyan állandó együtthatós, másodrendủ lineáris inhomogén differenciálegyenletre, melynek homogén általános megoldása $c_{1} e^{x}+c_{2} x e^{x}, c_{1}, c_{2} \in R$, és zavaró függvénye $\sin x$ :

2. Adja meg az $f(x, y, z)=\ln \frac{1}{1-x^{2}-y^{2}-z^{2}}$ függvény értelmezési tartományát! Hol helyezkednek el ezek a pontok a térben?.

3. Ha az $f(x, y, z)$ függvénynek $\left(x_{0}, y_{0}, z_{0}\right)$ stacionárius pontja és a Hesse-féle mátrix sarokdeterminánsai $\left(x_{0}, y_{0}, z_{0}\right)$-ban $D_{1}<0, D_{2}>0, D_{3}=0 \quad, \quad$ akkor $f(x, y, z)$ függvénynek $\left(x_{0}, y_{0}, z_{0}\right)$-ban

4. Egy hasáb egyik csúcsa a koordináta-rendszer origójában van, az ebből a csúcsból kiinduló élek pedig a tengelyek pozitív felére illeszkednek. Az $x$ tengelyre illeszkedő éle 3, az y-ra illeszkedő 4, a z-re illeszkedő 5 egységnyi hosszúságú. Számítsuk ki a tömegét, ha sűrüségfüggvénye: $s(x, y, z)=x^{2} y^{3} z^{4}$ (az eredményt elég hatvány alakban megadni)!

5. Adott $\bar{v}(x, y, z)=(z,-x,-y)$ és $\bar{r}(t)=(1-2 t, 3 t-2, t-1) ; \quad t \in[0 ; 2]$. Ekkor a vektor-vektor függvény vektor-skalár függvény mentén képzett vonalintegrálja (a végeredményt is számítsuk ki):

6. Az $f(x, y)=x^{2}+\sqrt{3} y$ függvény $T$ tartomány feletti felületének felszínét az

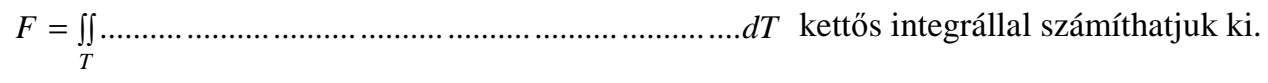

7. Нa $\bar{v}(x, y, z)=\left(y+x z^{3}\right) \bar{i}-x y \bar{j}+x^{2} z^{2} \bar{k}$, akkor div rot rot $\bar{v}(x, y, z)=$

\section{4. ábra. Példák kiegészítendő kérdésekre}

\section{4. Összefoglaló}

A matematika oktatás modernizálása időszerü, már megtettük a kezdeti lépéseket. Egyetemünk hallgatóinak MSc képzésében elsősorban az alkalmazásra kell törekedni és nem kell a mély matematikai háttérösszefüggéseket megtanítani (azok a megértésükhöz szükséges komoly alapismeretek hiányában úgyis a „levegőben lógnak”). Nem kell értés nélkül memorizáltatni képleteket, eljárások lépéseit, hiszen ezek a későbbiekben, a gyakorlati életben is mindig könnyen hozzáférhetök lesznek. A legfontosabb cél a felsőbb matematika jelölésrendszerének megismertetése, a matematikai gondolkodásmód kialakítása és a problémamegoldó készség fejlesztése.

\section{Irodalomjegyzék}

[1] http://www.oktatas.hu/kozneveles/erettsegi/prezentaciok_tanulmanyok

[2] http://www.nyme.hu 